\title{
Stadium dan Tingkat Parasitemia Plasmodium Falciparum pada Sediaan Darah Malaria
}

\section{Stages and Levels of Plasmodium Falciparum Parasitemia in Malaria Blood Preparations}

\author{
NANDA YUAN SAVERA \\ Jurusan Analis Kesehatan Poltekkes Kemenkes Semarang \\ Jl. Wolter Monginsidi Pedurungan Tengah Semarang \\ E-mail: nandayuansavera603@gmail.com
}

\begin{abstract}
Abstrak
Malaria merupakan suatu penyakit menular yang disebabkan oleh parasit plasmodium yang ditularkan melalui gigitan nyamuk Anopheles betina. Malaria terdapat beberapa stadium antara lain yaitu stadium tropozoit, skizon, dan gametosit. Plasmodium falciparum merupakan spesies paling berbahaya karena potensial menimbulkan hiperparasitemia dan komplikasi. Banjarnegara merupakan salah satu daerah endemis. Kasus malaria tahun 2017 dari Januari hingga Oktober jenis plasmodium yang paling sering ditemukan di Puskesmas Banjarmangu 1 Kabupaten Banjarnegara adalah Plasmodium falciparum. Jenis penelitian adalah penelitian observasional dengan kriteria penelitian secara deskriptif. Hasil Penelitian dari 24 sampel yang diperiksa yaitu stadium yang ditemukan adalah stadium dengan pola trofozoit sebanyak 14 sediaan, stadium dengan pola trofozoit-skizon 3 sediaan, dan stadium dengan pola trofozoit-gametosit sebanyak 7 sediaan. Tingkat parasitemia ditemukan 2 tingkat parasitemia yaitu $0,02 \%$ dan $0,2 \%$. Ditemukan 3 pola stadium yaitu trofozoit, trofozoit-skizon, dan trofozoit-gametosit. Untuk tingkat parasitemia dari seluruh sediaan yang diperiksa tidak ditemukan adanya hiperparasiemia.
\end{abstract}

Kata Kunci: Stadium ; Tingkat Parasitemia ; Plasmodium falciparum.

\begin{abstract}
Malaria is an infectious disease caused by plasmodium parasites that are infected through the bite of anopheles female mosquito. Malaria has several stages such as tropozoites, schizonts and gametocytes stage. Plasmodium falciparum is the most dangerous species because of the potential to cause hyperparasitemia and complications. Banjarnegara is one of endemic areas. The cases of malaria in 2017 from January to October, the most common type of plasmodium found in community health care center Banjarmangu 1 district Banjarnegara is Plasmodium falciparum. Research method was observational study with descriptive research criteria. The result of this study from 24 blood samples examined were stadium with tropozoites stage amount 14 samples, stadium with tropozoit-schizonts stage of 3 samples and stadium with tropozoit-gametocytes stage of 7 samples. Levels of parasitemia was found 2 levels of parasitemia that is $0,02 \%$ and $0,2 \%$. there were 3 stadium found that are tropozoit, tropozoit-schizonts and tropozoit-gametocytes. To level of parasitemia, there was no found hyperparasitemia of all the examined samples.
\end{abstract}

Keyword: Stadium ; Level of Parasitemia ; Plasmodium Falciparum

\section{Pendahuluan}

Malaria merupakan suatu penyakit menular yang disebabkan oleh parasit plasmodium yang ditularkan ke manusia melalui gigitan nyamuk Anopheles betina. Malaria pada manusia terdapat empat spesies yaitu Plasmodium falciparum, Plasmodium vivaks, Plasmodium 
malaria, Plasmodium ovale. Secara garis besar malaria terdapat beberapa stadium antara lain yaitu stadium tropozoit, stadium skizon, dan stadium gametosit.

Dwithania, Irawati, dan Rasyid (2013) menyatakan bahwa "penyakit malaria masih merupakan infeksi parasitik paling penting di dunia, diperkirakan terdapat lebih dari 500 juta kasus malaria pertahun dengan 3 juta kematian. Penyakit malaria ini masih merupakan masalah kesehatan dunia, termasuk Indonesia karena angka kesakitan dan kematian akibat penyakit ini cukup tinggi”. Menurut Hartono (2012), di Provinsi Jawa Tengah "angka kesakitan malaria sejak tahun 2010 sebesar 0,92\%o, tahun 2011 meningkat menjadi $0,97 \%$, dan tahun 2012 turun menjadi 0,68\%" (dalam Saputro, Siwiendrayanti, dan Hartono, 2015, p. 77).

Salah satu daerah endemis di Provinsi Jawa Tengah yaitu Kabupaten Banjarnegara. Kasus malaria pada tahun 2007 mulai menunjukkan peningkatan. Kasus malaria pada tahun 2011 tercatat sebanyak 843 kasus dengan nilai Annual Parasite Incidence (API) sebesar 0,87\% ; tahun 2012 sebanyak 592 kasus dengan nilai API sebesar 0,61\%o dan tahun 2013 sebanyak 407 kasus dengan nilai API 0,42\%o, serta di tahun 2015 nilai API 0,33\%o dengan kasus sebanyak 323 kasus. Beberapa wilayah endemis malaria di wilayah Kabupaten Banjarnegara antara lain Kecamatan Banjarmangu, Wanadadi, Pagedongan dan Punggelan. (Dinas Kesehatan Kabupeten Banjarnegara, 2016)

Tahun 2016 kasus malaria di Kabupaten Banjarnegara mencapai 222 kasus. Beberapa Puskesmas di wilayah Kabupaten Banjarnegara yang terdapat kasus malaria antara lain Puskesmas Banjarmangu 1, Banjarmangu 2, Wanadadi 1, Pagedongan, Punggelan 2, Bawang 1, dan Purwanagara 1. Puskesmas di wilayah Kabupaten Banjarnegara dengan kasus malaria tertinggi pada tahun 2016 adalah Puskesmas Banjarmangu 1 dengan jumlah kasus sebanyak 102 kasus. Puskesmas Banjarmangu 2 sebanyak 25 kasus, Puskesmas Wanadadi 1 sebanyak 87 kasus, Puskesmas Pagedongan dan Puskesmas Punggelan 2 ditemukan sebanyak 3 kasus, kemudian Puskesmas Bawang dan Puskesmas Purwanegara hanya ditemukan 1 kasus. (Dinas Kesehatan Kabupeten Banjarnegara, 2016)

Kasus malaria tahun 2017 dari bulan Januari hingga bulan Oktober jenis plasmodium yang paling sering ditemukan di Puskesmas Banjarmangu 1 Kabupaten Banjarnegara adalah Plasmodium falciparum. Menurut Harijanto (2000), Plasmodium falciparum merupakan penyebab malaria tropikana. Parasit ini adalah spesies paling berbahaya karena potensial menimbulkan hiperparasitemia dan komplikasi.

Berdasarkan latar belakang tersebut peneliti tertarik untuk meneliti Stadium dan tingkat parasitemia Plasmodium falciparum pada sediaan darah malaria di Puskesmas Banjarmangu 1 Kabupaten Banjarnegara periode tahun 2017.

Meneliti stadium dan tingkat parasitemia Plasmodium falciparum pada sediaan darah malaria di Puskesmas Banjarmangu 1 Kabupaten Banjarnegara maka peneliti dapat menggambarkan kondisi klinis penderita.

Darah yang terinfeksi malaria falciparum bentuk cincin stadium tropozoit muda Plasmodium falciparum sangat kecil dan halus dengan ukuran kira kira seperenam diameter eritrosit. Stadium tropozoit yang ditemukan di dalam darah dapat membantu diagnosis spesies (Susanto dkk., 2008). Rustandi (2013) menjelaskan bahwa "ditemukannya stadium skizon dalam darah dapat menunjukan keadaan klinis yang buruk dan kemungkinan tingginya tingkat parasitemia, sedangkan ditemukannya stadium gametosit merupakan stadium infektif pada nyamuk, sehingga dapat dipergunakan untuk memprediksi suatu daerah yang memiliki peluang menjadi daerah endemik. Selain itu, stadium gametosit yang ditemukan dapat dipergunakan untuk memberikan gambaran lamanya infeksi”.

\section{Metode}

Jenis penelitian yang digunakan peneliti dalam penelitian ini adalah penelitian observasional (non-eksperimen) dengan kriteria penelitian secara deskriptif. Jenis penelitian observasional deskriptif dilakukan yaitu melihat stadium dan tingkat parasitemia 
Plasmodium falciparum pada sediaan darah malaria di Puskesmas Banjarmangu 1 Kabupaten Banjarnegara periode tahun 2017.

\section{Hasil dan Pembahasan}

\section{a. Stadium Plasmodium falciparum}

Tabel 1. Data Hasil Pemeriksaan Stadium Plasmodium falciparum di Puskesmas Banjarmangu 1 periode tahun 2017

\begin{tabular}{ccc}
\hline Pola & \multicolumn{2}{c}{ Jumlah } \\
\cline { 2 - 3 } Stadium & $\mathrm{N}$ & $\%$ \\
\hline Tr & 14 & $58 \%$ \\
Tr-Sk & 3 & $13 \%$ \\
Tr-Gm & 7 & $29 \%$ \\
\hline Jumlah & 24 & $100 \%$ \\
\hline
\end{tabular}

Keterangan :

$\operatorname{Tr}:$ Tropozoit

$\operatorname{Tr}-\mathrm{Sk} \quad$ :Tropozoit dan Skizon

$\mathrm{Tr}-\mathrm{Gm}$ : Tropozoit dan Gametosit

Berdasarkan hasil penelitian 24 sediaan, ditemukan 3 pola stadium yaitu pola stadium tropozoit, stadium tropozoit-skizon, dan stadium tropozoit-gameosit. Sediaan dengan pola stadium tropozoit sebanyak 14 sediaan, hal ini karena stadium ini merupakan awal terbentuknya infeksi parasit pada darah yang berasal dari merozoit. Pada siklus hidup Plasmodium falciparum ini, sekitar 40.000 merozoit hati masuk ke peredaran darah untuk menginfeksi eritrosit. Merozoit yang masuk kedalam eritrosit akan tumbuh menjadi tropozoit. Stadium ini juga memiliki waktu terpanjang dalam siklus kehidupan malaria, oleh karena itu semua sediaan positif ditemukan stadium tropozoit.

Sediaan dengan pola stadium tropozoit dan skizon ditemukan sebanyak 3 sediaan. Bentuk skizon baru dapat ditemukan pada sediaan, bila pengambilan darah dilakukan dekat pada jam sebelum atau sesudah sporulasi, oleh karena itu, hanya 3 sediaan yang ditemukan adanya skizon. Adanya stadium skizon Plasmodium falciparum dalam sediaan darah tepi berarti keadaan infeksi berat, sehingga merupakan indikasi untuk tindakan pengobatan cepat (Rustandi, 2013)

Sediaan dengan pola stadium tropozoit dan gametosit sebanyak 7 sediaan. Stadium gametosit menandakan infeksi sudah berlangsung lama, karena gametosit yang ada pada darah tepi paling cepat 1 minggu setelah pasien mengalami demam pertama. Stadium gametosit sendiri merupakan stadium infektif pada nyamuk, sehingga dapat dipergunakan untuk memprediksi suatu daerah yang memiliki peluang menjadi daerah endemik.

\section{b. Tingkat Parasitemia Plasmodium falciparum}

Hasil dari pemeriksaan tingkat parasitemia Plasmodium falciparum dari 24 sediaan malaria falciparum ditemukan dua tingkat parasitemia yaitu $0,02 \%$ dan $0,2 \%$ dan dapat dilihat pada tabel 4.3.

Tabel 2. Data Hasil Pemeriksaan Tingkat Parasitemia Plasmodium falciparum di Puskesmas Banjarmangu 1 periode tahun 2017 


\begin{tabular}{ccc}
\hline Tingkat & \multicolumn{2}{c}{ Jumlah } \\
\cline { 2 - 3 } Parasitemia & $\mathrm{n}$ & $\%$ \\
\hline $0,02 \%$ & 8 & $34 \%$ \\
$0,2 \%$ & 16 & $66 \%$ \\
\hline Jumlah & 24 & $100 \%$ \\
\hline
\end{tabular}

Berdasarkan pengamatan secara mikroskopis dan di tabel 2, dapat diketahui sediaan dengan jumlah paling banyak ditemukan yaitu sediaan dengan tingkat parasitemia $0,2 \%$ sebesar $66 \%$. Nilai ini berdasarkan tabel determinasi parasitemia dengan hubungan klinis Menurut Hensheid, 1999 (tabel 2.2), menunjukkan bahwa diatas level ini kekebalan pasien akan menimbulkan gejala klinis yang tinggi. Dari seluruh sediaan yang diperiksa sejumlah 24 tidak ditemukannya adanya hiperparasitemia atau malaria berat pada sediaan darah malaria yang diteliti, karena seluruh sediaan kepadatan parasit $<100.000 / \mu 1$ darah atau tingkat parasitemia $<2 \%$.

\section{c. Stadium dan Tingkat Parasitemia Plasmodium falciparum}

Sediaan darah tebal malaria dengan positif Plasmodium falciparum yang berjumlah 24, diperiksa untuk menghitung stadium dan tingkat parasitemia parasit Plasmodium falciparum dan menghitung jumlah parasit per 200 leukosit. Data hasil pemeriksaan stadium dan tingkat parasitemia disajikan dalam tabel 4.4

Tabel 3. Hasil pemeriksaan stadium dan tingkat parasitemia Plasmodium falciparum di Puskesmas Banjarmangu 1 periode tahun 2017

\begin{tabular}{|c|c|c|c|c|c|c|c|c|}
\hline Tingkat & \multicolumn{8}{|c|}{ Stadium } \\
\hline Parasitemi & & & & -Sk & & $\mathrm{Gm}$ & & mlah \\
\hline $\mathrm{a}$ & $\mathrm{n}$ & $\%$ & $\mathrm{~N}$ & $\%$ & $\mathrm{n}$ & $\%$ & $\mathrm{n}$ & $\%$ \\
\hline $0,02 \%$ & 4 & $\begin{array}{l}16 \\
\%\end{array}$ & 2 & $9 \%$ & 2 & $9 \%$ & 8 & $34 \%$ \\
\hline $0,2 \%$ & $\begin{array}{l}1 \\
0\end{array}$ & $\begin{array}{l}42 \\
\%\end{array}$ & 1 & $4 \%$ & 5 & $\begin{array}{l}20 \\
\%\end{array}$ & $\begin{array}{l}1 \\
6\end{array}$ & $66 \%$ \\
\hline Jumlah & $\begin{array}{l}1 \\
4\end{array}$ & $\begin{array}{l}58 \\
\%\end{array}$ & 3 & $\begin{array}{l}13 \\
\%\end{array}$ & 7 & $\begin{array}{l}29 \\
\%\end{array}$ & $\begin{array}{l}2 \\
4\end{array}$ & $100 \%$ \\
\hline
\end{tabular}

Keterangan :

$\operatorname{Tr} \quad$ : Tropozoit

$\operatorname{Tr}-\mathrm{Sk} \quad$ : Tropozoit dan Skizon

Tr - Gm : Tropozoit dan Gametosit

Berdasarkan tabel 3, stadium tropozoit sebesar $16 \%$ sering ditemukan pada tingkat parasitemia $0,02 \%$, sedangkan stadium dengan pola tropozoit-skizon dan tropozoit-gametosit ditemukan sebesar $9 \%$. Tingkat parasitemia $0,2 \%$ paling sering dijumpai yaitu stadium tropozoit sebesar $42 \%$, dengan jumlah 10 sediaan, jumlah ini merupakan jumlah terbanyak dibandingkan pola stadium yang lain. Stadium tropozoit ini merupakan awal terbentuknya infeksi parasit pada darah yang berasal dari merozoit. Kemudian untuk tingkat parasitemia $0,2 \%$ dengan pola tropozoit-skizon ditemukan sebesar $4 \%$. Berdasarkan sekuestrasi apabila ditemukan adanya stadium skizon Plasmodium falciparum dalam sediaan darah tepi berarti keadaan infeksi berat, sehingga merupakan indikasi untuk tindakan pengobatan cepat. Tingkat parasitemia $0,2 \%$ dengan pola tropozoit-gametosit sebesar $20 \%$. Stadium gametosit menandakan infeksi sudah berlangsung lama. Penderita dengan ditemukannya gametosit dapat berpotensi menularkan penyakit. Stadium gametosit sendiri merupakan stadium infektif pada nyamuk, sehingga dapat dipergunakan untuk memprediksi suatu daerah yang memiliki peluang menjadi daerah endemik. 


\section{Simpulan dan Saran}

\section{Simpulan}

Stadium Plasmodium falciparum pada sediaan darah malaria di Puskesmas Banjarmangu 1 Kabupaten Banjarnegara periode tahun 2017 ditemukan 3 pola stadium yaitu stadium tropozoit sebesar 58\%, stadium tropozoit-skizon sebesar $13 \%$, dan stadium tropozoit-gametosit sebesar $29 \%$.

Tingkat parasitemia Plasmodium falciparum pada sediaan darah malaria di Puskesmas Banjarmangu 1 Kabupaten Banjarnegara periode tahun 2017 didapatkan hasil ditemukan 2 tingkat parasitemia yaitu $0,02 \%$ dan $0,2 \%$ dan dari seluruh sediaan yang diperiksa tidak ditemukan adanya hiperparasitemia.

Stadium dan tingkat parasitemia pada sediaan darah yang diperiksa dapat disimpulkan bahwa stadium pada tingkat parasitemia $0,02 \%$ maupun $0,2 \%$ yang paling sering ditemukan adalah stadium dengan pola tropozoit, dan dapat diketahui bahwa kasus malaria falciparum di Puskesmas Banjarmangu 1 pada tahun 2017 dari 24 sampel yang diperiksa tidak menunjukkan adanya malaria berat karena tidak ditemukan adanya hiperparasitemia.

\section{Daftar Pustaka}

Dinas Kesehatan Kabupaten Banjarnegara. 2016. Laporan Hasil Penyelidikan Epidemiologi dan MBS/Survey Malaria di Kabupaten Banjarnegara Tahun 2016

Dwithania, M., Irawati, N., \& Rasyid, R. 2013. Insiden Malaria di Puskesmas Sungai Durian dan Puskesmas Talawi Kota Sawahlunto Bulan Oktober 2011 sampai Februari 2012. Jurnal Keseatan Andalas , 76.

Harijanto, P. (Eds). 2000. Malaria: Epidemiologi, Patogenesis, Manifestasi Klinis dan Penanganan. Jakarta: Penerbit Buku Kedokteran EGC.

Rustandi, T. 2013. Karya Tulis Ilmiah. Gambaran Stadium dan Tingkat Parasitemia Malaria Vivaks di Kecamatan Simpenan Kabupaten Sukabumi. Bandung

Saputro, K. P., \& Siwiendrayanti, A. 2015. Hubungan Lingkungan Sekitar Rumah dan Praktik Pencegahan dengan Kejadian Malaria di Desa Kendaga Kecamatan Banjarmangu Kabupaten Banjarnegara Tahun 2013. Unnes Journal of Publick Health, 77.

Sutanto, I., Ismid, I. S., Sjarifuddin, P. K., \& Sungkar, S. (Eds). 2008. Buku Ajar Parasitologi Kedokteran. Jakarta: Balai Penerbit FKUI, Jakarta. 